\title{
Alkali Solution Erodes Shale: Influencing Factors and Structural Damage Characteristics
}

\author{
Jiping She $\mathbb{D}^{1,2}$ Hao Zhang $\mathbb{D}^{1,2}$ Ying Zhong $\mathbb{D}^{1,2}$ Yang Yuan, ${ }^{1,2}$ and Jiachun You ${ }^{1,2}$ \\ ${ }^{1}$ College of Energy, Chengdu University of Technology, Chengdu, Sichuan 610059, China \\ ${ }^{2}$ State Key Lab of Oil and Gas Reservoir Geology and Exploitation, Chengdu University of Technology, Chengdu, \\ Sichuan 610059, China \\ Correspondence should be addressed to Hao Zhang; zhanghao@cdut.edu.cn
}

Received 16 May 2018; Accepted 16 July 2018; Published 16 August 2018

Academic Editor: Guillaume Galliero

Copyright (C) 2018 Jiping She et al. This is an open access article distributed under the Creative Commons Attribution License, which permits unrestricted use, distribution, and reproduction in any medium, provided the original work is properly cited.

\begin{abstract}
High-pH drilling fluids are often used for drilling shale gas wells. Alkali erosion of shale is one of the important factors of wellbore instability. Alkali erosion experiments of different kinds of minerals and shale were conducted in this paper. Experimental results show that the corrosion rate of kaolinite is the highest when the $\mathrm{pH}$ is 9, the corrosion rate of smectite is the highest when the $\mathrm{pH}$ is 10 or 11 , and the corrosion rate of the quartz is the highest when the $\mathrm{pH}$ is 12 . Both shale particle size and concentration of hydroxide ion all affect the reaction rate, and the former has a negative correlation with the reaction rate, and the latter has a positive correlation with the reaction rate. In addition, alkaline erosion can lead to the fracture propagation along the bedding planes of shale, which can easily result in wellbore instability. This study may offer some theoretical basis for wellbore instability induced by high-pH drilling fluids.
\end{abstract}

\section{Introduction}

Wellbore instability is common in the process of shale formation drilling and completion. It not only increases nonproduction time and cost, but also becomes a serious challenge to drill safely and efficiently. Wellbore instability is primarily a function of rock response to the stress concentration induced around the wellbore during drilling. If the strength of the rock is higher than these stresses, the borehole will be stable; otherwise, rock will yield and may collapse, detach, or converge according to factors such as fluid properties, strength, and the failure behavior of rock $[1,2]$.

The strength of the shale will be reduced due to the interaction between the drilling fluid and shale. Water molecules of the drilling fluid enter the pores of shale by means of displacing pressure, infiltration, diffusion, and so on $[3,4]$. Clay minerals such as smectite swell when water goes in, which will produce swelling stress. This stress can lead to the shale dispersion and bedding propagation, which decreases the strength of shale sharply [5]. To prevent clay minerals from hydrating swelling, some inhibitory agents such as $\mathrm{KCl}$ are generally added into the drilling fluid. But, for some kinds of shale, these agents do not have the inhibitive effect. Instead, it increases the shale's dispersion. For example, the strength of kaolinite-rich shale will lose strength when exposed to $\mathrm{KCl}$ due to chemical transformation of the kaolinite minerals [6,7]. The oil-based drilling fluid greatly solves the problem of clay minerals hydration swelling. However, the wellbore instability is still unable to be avoided by using this fluid. On the one hand, the oil-based drilling fluid contains a little water, which leads to a small swelling and reduces the strength of the shale. On the other hand, in order to keep good emulsifying properties, the oil-based drilling fluid generally has strong alkaline. Some minerals of shale are easily eroded by alkali, which also leads to wellbore instability [7-9].

In addition, the wellbore instability is also concerned with the structural integrity of the rock mass. On the one hand, if the rock has many weak bedding planes and fractures, the wellbore instability is easy to happen when the weak bedding plane destructs or slides [10]. On the other hand, the bedding planes and natural fractures can propagate due to lost circulation. Lost circulation can cause the 
decrease of borehole pressure and the damage of wall surrounding rock and then induces the collapse of wellbore [11-15].

This paper took the LMX shale formation in Sichuan Basin as the object of study. Wellbore instability had been the main downhole complex problem in the process of drilling (Figure 1) and unable to be avoided even if using a strong inhibitory water-based or oil-based drilling fluid. According to the analysis, the instability was mainly caused by high $\mathrm{pH}(\mathrm{pH}=11 \sim 12)$ of drilling fluids (Table 1). In this paper, a new insight was proposed on why wellbore instability can be induced by high-pH drilling fluids, in terms of some chemical reaction experiments on both high-pH solution and shale.

\section{Samples and Experimental Methods}

\subsection{Samples Used}

2.1.1. Single Mineral. Five types of single mineral were used in the experiments, which were quartz, smectite, kaolinite, illite, and chlorite (Figure 2). These single mineral were from geological specimens company of Hangzhou.

2.1.2. Shale. In this study, LMX shale was used in the experiments. The mineralogical composition and other parameters of shale are listed in Table 2. It contains $39.3 \%$ clay, which included illite (84.9\%), illite/smectite (2.2\%), kaolinite (10.3\%), and chlorite (2.6\%).

2.1.3. Fluids. In order to eliminate the interference of bentonite and treatment agents in drilling fluids, alkali solutions with different $\mathrm{pH}$ were used instead of the high-pH drilling fluid in the experiments. Two types of alkaline solutions were used in this study. The $\mathrm{pH}$ of alkali solutions is 9 to 12 .

\subsection{Experimental Methods}

2.2.1. Alkaline Erosion Experiment of Mineral. Dry mineral powder (particle size is 1 to $10 \mu \mathrm{m}$ ) is soaked in alkali solutions for 24 hours under $70^{\circ} \mathrm{C}$. In this reaction, the weight of the mineral powder sample is $10 \mathrm{~g}$, and the solid-liquid ratio is $1: 30$. After the reaction, the solid phase is filtered and dried. The weight of the solid phase after the reaction is recorded as $W$. The erosion rate is calculated as shown in the following equation:

$$
\text { erosion rate }=\frac{10.00-W}{10.00} \times 100 \%
$$

2.2.2. Alkaline Erosion Experiment of Shale Particles. Shale particles were evaluated by alkaline erosion experiment. Shale particles were crushed into particles with three different particle sizes $(1 \sim 10 \mu \mathrm{m}, 25 \sim 60 \mu \mathrm{m}$, and 75 100 $\mu \mathrm{m}$, resp.) and then soaked in the different $\mathrm{pH}$ alkali solutions under the $70^{\circ} \mathrm{C}$ condition. After $24 \mathrm{~h}$, the samples were filtered, dried, and weighed.

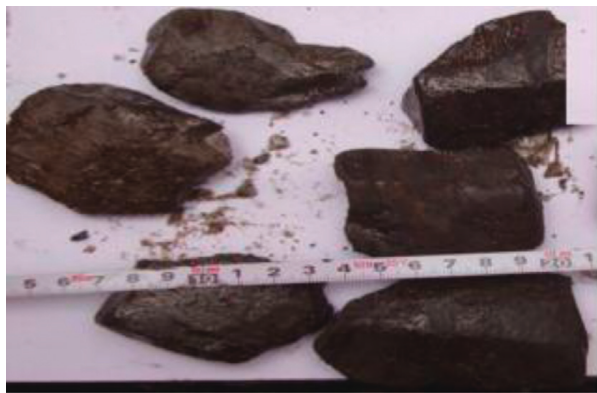

FIgURE 1: The debris back from the wellhead of W-H1 well (LMX formation) [16].

2.2.3. Alkaline Erosion Experiment of Shale. For the shale pieces, the experimental procedures were as follows:

(1) Cut shale pieces with the diameter of $25 \mathrm{~mm}$ and the thickness of $4 \mathrm{~mm}$ from the same shale core plug.

(2) Select one piece of the shale sample to soak into distilled water and solutions with the $\mathrm{pH}$ of $9,10,11$, and 12 , respectively.

(3) Put the different solutions with shale pieces into different aging cells of a roller furnace.

(4) Set the temperature of the roller furnace to $70^{\circ} \mathrm{C}$ and run the roller furnace.

(5) After 1 day, 3 days, and 7 days, open the roller furnace to take photos for shale pieces, respectively.

\section{Results and Discussion}

3.1. Effect of Mineral Types on Alkaline Erosion. For the reaction mechanism of rock minerals and alkaline fluids, researchers showed that common minerals (including quartz, feldspar, and clay minerals) can react with alkaline fluids. The reaction of common minerals with sodium hydroxide solution is shown in Table 3 .

According to the reaction formula in Table 3, if minerals are exposed to alkaline fluids, minerals will be lost and some new products will be generated. As shown in Figure 3, alkali erosion experiments of minerals show that both quartz and clay minerals can react with the alkaline solution. When the $\mathrm{pH}$ was 9 , the corrosion rate of kaolinite was $6.9 \%$, and the corrosion rates of quartz and smectite were similar, which were $4.2 \%$ and $3.9 \%$, respectively. The corrosion rates of illite and chlorite were $1.9 \%$ and $1.6 \%$, respectively. The corrosion rates of the five minerals are as follows: kaolinite $>$ smectite $>$ quartz $>$ illite $>$ chlorite. When the $\mathrm{pH}$ was 10 , the corrosion rates of quartz, montmorillonite, illite, kaolinite, and chlorite are $9.5 \%, 10.8 \%, 7.0 \%, 1.5 \%$, and $0.5 \%$, respectively. The corrosion rates of the five minerals are as follows: smectite $>$ quartz $>$ kaolinite $>$ illite $>$ chlorite. When the $\mathrm{pH}$ increased to 11, the corrosion rates of quartz, smectite, illite, kaolinite, and chlorite further increased, and the corrosion rates were $7.8 \%, 11.8 \%, 7.2 \%, 1.7 \%$ and $1.0 \%$, respectively. The corrosion rates of the five minerals are also as follows: smectite $>$ quartz $>$ kaolinite $>$ illite $>$ chlorite. When the $\mathrm{pH}$ reached 12 , the corrosion rate of illite 
TABLE 1: Downhole problems during drilling shale wells in Sichuan Basin and Ordos Basin.

\begin{tabular}{|c|c|c|c|c|}
\hline Wells & Basins & Formations & $\mathrm{pH}$ of drilling fluids & Downhole problems \\
\hline W-H1 & Sichuan & Longmaxi & $11.0 \sim 11.5$ & $\begin{array}{l}\text { Borehole collapse occurred and a large amount of } \\
\text { black collapsed debris with a size of } 5 \sim 8 \mathrm{~cm} \text { returned } \\
\text { from the well head when drilling shale formations } \\
\qquad(1856 \sim 2611 \mathrm{~m})\end{array}$ \\
\hline W-H3 & Sichuan & Qiongzhusi & $11.0 \sim 11.5$ & $\begin{array}{l}\text { Serious shale collapse caused pipe sticking at } \\
3642.24 \mathrm{~m} \text { so drilling finished in advance }\end{array}$ \\
\hline $\mathrm{N}-\mathrm{H} 1$ & Sichuan & Longmaxi & $11.0 \sim 11.5$ & $\begin{array}{l}\text { Shale sloughing often occurred, and a large amount of } \\
\text { black collapsed shale debris returned from the well } \\
\text { head during drilling; pipe stuck happened when } \\
\text { picking out drilling tools }\end{array}$ \\
\hline Y1 & Sichuan & Longmaxi & $11.0 \sim 11.5$ & $\begin{array}{l}\text { Serious lost circulation and shale collapse occurred } \\
\text { when drilling a horizontal zone }\end{array}$ \\
\hline Z101 & Sichuan & Niutitang & $11.0 \sim 12.0$ & Serious wellbore diameter enlargement \\
\hline DP1 & Ordos & Yanchang & $11.0 \sim 12.0$ & $\begin{array}{l}\text { Serious lost circulation (leakage volume was } 177 \mathrm{~m}^{3} \text { ) } \\
\text { and shale collapse occurred when drilling from } 1960 \\
\text { to } 2100 \mathrm{~m}\end{array}$ \\
\hline $\mathrm{JH}-\mathrm{x} 2$ & Ordos & Yanchang & $10.0 \sim 11.0$ & $\begin{array}{l}\text { Ratio of wellbore diameter enlargement ranging from } \\
\qquad 38 \% \text { to } 60 \%\end{array}$ \\
\hline
\end{tabular}
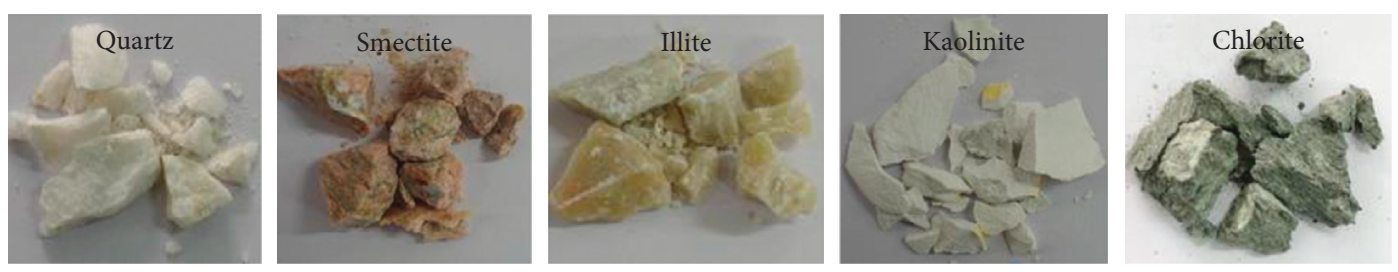

FIgURE 2: Quartz and clay minerals.

TABLE 2: Basic parameters of LMX formation of Sichuan Basin.

\begin{tabular}{|c|c|c|c|c|c|c|c|c|c|}
\hline \multicolumn{6}{|c|}{ X-ray: whole sample, wt.\% } & \multicolumn{4}{|c|}{ X-ray: clay mineral relative percentage, wt.\% } \\
\hline Quartz & Dolomite & Feldspar & Dolomite & Pyrite & Total clay & Illite & Illite/smectite & Kaolinite & Chlorite \\
\hline 45.9 & 1.4 & 7.2 & 3.5 & 2.7 & 39.3 & 84.9 & 2.2 & 10.3 & 2.6 \\
\hline
\end{tabular}

TABLE 3: Chemical reaction formula of minerals and sodium hydroxide solution.

\begin{tabular}{|c|c|c|}
\hline Mineral & Chemical reaction formula & References \\
\hline Quartz & $\mathrm{SiO}_{2}(\mathrm{~s})+\mathrm{NaOH}+\mathrm{H}_{2} \mathrm{O}=\mathrm{NaH}_{3} \mathrm{SiO}_{4}$ & {$[17,18]$} \\
\hline Feldspar & $\begin{aligned} \mathrm{Al}_{2} \mathrm{O}_{3}+2 \mathrm{NaOH} & =2 \mathrm{NaAlO}_{2}+\mathrm{H}_{2} \mathrm{O} \\
\mathrm{SiO}_{2} & +2 \mathrm{NaOH}=\mathrm{Na}_{2} \mathrm{SiO}_{3}+\mathrm{H}_{2} \mathrm{O}\end{aligned}$ & {$[8,19]$} \\
\hline Dolomite & $\begin{array}{c}\mathrm{CaMg}\left(\mathrm{CO}_{3}\right)_{2}+2 \mathrm{Na}^{+}+2 \mathrm{OH}^{-}=\mathrm{CaCO}_{3}+\mathrm{Mg}(\mathrm{OH})_{2}+\mathrm{Na}_{2} \mathrm{CO}_{3} \\
\mathrm{Al}_{2} \mathrm{Si}_{4} \mathrm{O}_{10}(\mathrm{OH})_{2}+10 \mathrm{H}_{2} \mathrm{O}=2 \mathrm{Al}(\mathrm{OH})_{3}+2 \mathrm{Si}(\mathrm{OH})_{4}\end{array}$ & {$[8,20]$} \\
\hline Smectite & $\begin{array}{c}5 \mathrm{Al}_{2} \mathrm{Si}_{4} \mathrm{O}_{10}(\mathrm{OH})_{2}+12 \mathrm{Na}^{+}+2 \mathrm{Al} \\
(\mathrm{OH})_{3}+12 \mathrm{OH}^{-}+10 \mathrm{H}_{2} \mathrm{O}=4 \mathrm{Na}_{3} \mathrm{Al}_{3} \mathrm{Si}_{5} \mathrm{O}_{16} \cdot 6 \mathrm{H}_{2} \mathrm{O} \\
\mathrm{Al}_{2} \mathrm{Si}_{2} \mathrm{O}_{5}(\mathrm{OH})_{4}+5 \mathrm{H}_{2} \mathrm{O}=2 \mathrm{Al}(\mathrm{OH})_{3}+2 \mathrm{Si}(\mathrm{OH})_{4} \\
\mathrm{Al}_{2} \mathrm{Si}_{2} \mathrm{O}_{5}(\mathrm{OH})_{4}+2 \mathrm{Na}^{+}+2 \mathrm{OH}^{-}+4 \mathrm{Si}\end{array}$ & {$[21]$} \\
\hline Kaolinite & $\begin{array}{c}(\mathrm{OH})_{4}=2 \mathrm{NaAl}_{3} \mathrm{Si}_{3} \mathrm{O}_{3}+11 \mathrm{H}_{2} \mathrm{O} \\
\mathrm{Al}_{2} \mathrm{Si}_{2} \mathrm{O}_{5}(\mathrm{OH})_{4}+2 \mathrm{Na}^{+}+2 \mathrm{OH}^{-}+2 \mathrm{Si} \\
(\mathrm{OH})_{4}=2 \mathrm{NaA}_{1} \mathrm{Si}_{2} \mathrm{O}_{6} \cdot \mathrm{H}_{2} \mathrm{O}+5 \mathrm{H}_{2} \mathrm{O}\end{array}$ & {$[22,23]$} \\
\hline Illite & $\begin{array}{c}\left(\mathrm{K}, \mathrm{H}_{3} \mathrm{O}^{+}\right)(\mathrm{Al}, \mathrm{Mg}, \mathrm{Fe})_{2}\left[(\mathrm{Si}, \mathrm{Al})_{4} \mathrm{O}_{10}\right](\mathrm{OH})_{2}+\mathrm{OH}^{-} \rightarrow \mathrm{Al} \\
(\mathrm{OH})_{3}+\mathrm{K}^{+}+\mathrm{Fe}^{2+}+\mathrm{Mg}^{2+}+\mathrm{SiO}_{3}{ }^{2-} \\
\mathrm{Y}_{3}\left[\mathrm{Z}_{4} \mathrm{O}_{10}\right](\mathrm{OH})_{2}+\mathrm{Y}_{3}(\mathrm{OH})_{6}+\mathrm{OH}^{-} \rightarrow \mathrm{Al}(\mathrm{OH})_{3}+\mathrm{Fe}^{2+}+\mathrm{Fe}^{3+}\end{array}$ & [19] \\
\hline Chlorite & $\begin{array}{c}+\mathrm{Mg}^{2+}+\mathrm{B}^{3+}+\mathrm{SiO}_{3}{ }^{2-}+\mathrm{K}^{+}(\mathrm{Y}-\mathrm{Mg}, \mathrm{Al}, \mathrm{Fe} \\
\left.\mathrm{Z}-\mathrm{Si}, \mathrm{Al}, \mathrm{Fe}^{3+}, \mathrm{B}^{3+}\right)\end{array}$ & [19] \\
\hline Pyrite & $\begin{array}{c}\mathrm{FeS}_{2}+\underset{(\text { electrochemical reaction })}{2 \mathrm{OH}^{-} \rightarrow \mathrm{Fe}(\mathrm{OH})_{2}+\mathrm{SO}_{4}^{2-}+14 \mathrm{e}} \\
\end{array}$ & {$[24]$} \\
\hline
\end{tabular}




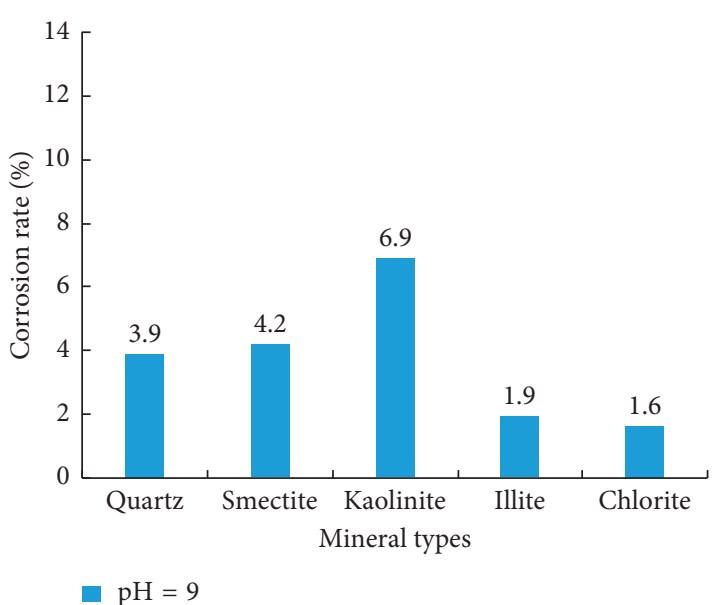

(a)

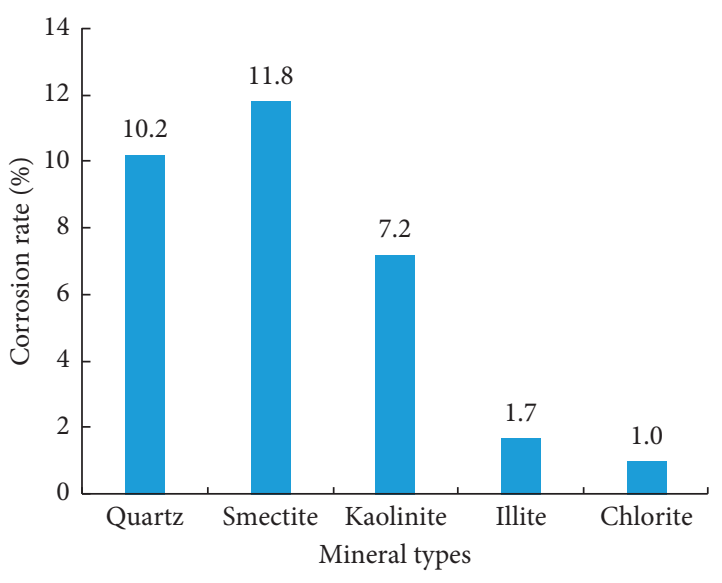

a $\mathrm{pH}=11$

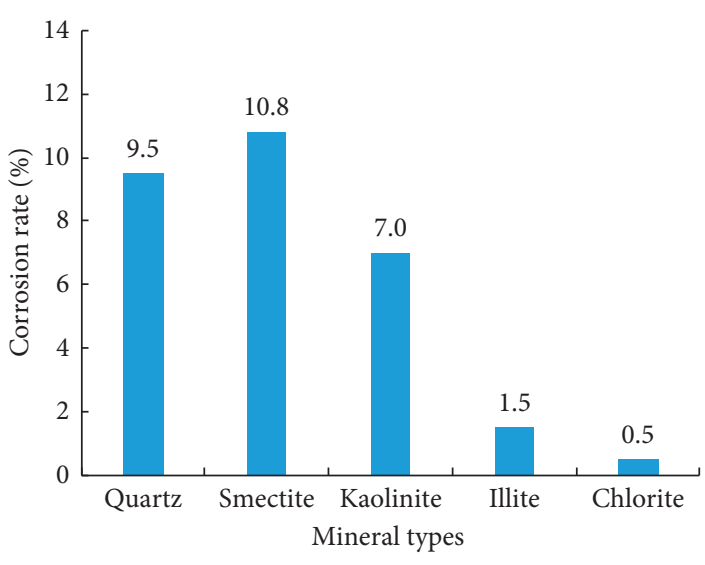

- $\mathrm{pH}=10$

(b)

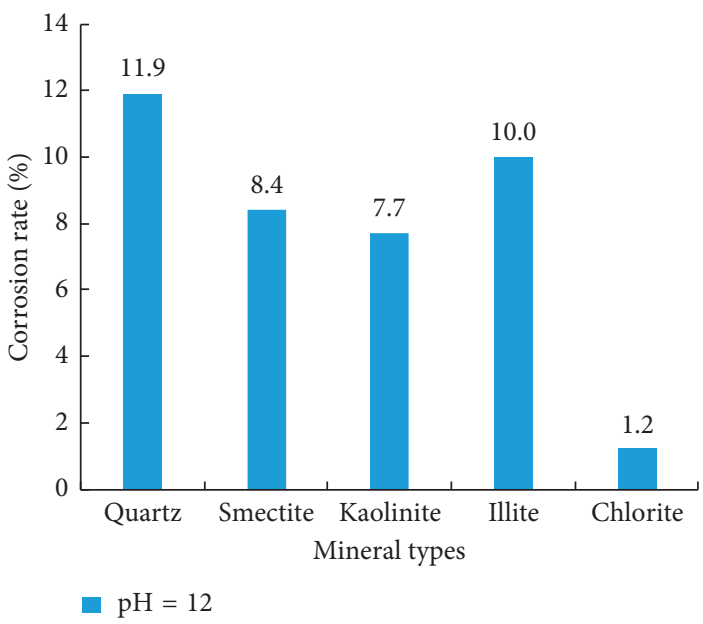

(d)

(c)

Figure 3: Corrosion rate of mineral under different $\mathrm{pH}$.

significantly increased, while the corrosion rate of smectite showed a decreasing trend. So, the corrosion rates of the quartz, smectite, illite, kaolinite, and chlorite were $11.9 \%$, $8.4 \%, 7.7 \%, 10.0 \%$, and $1.2 \%$, respectively. The corrosion rates of the five minerals are as follows: quartz $>$ illite $>$ smectite $>$ kaolinite $>$ chlorite.

So, when the $\mathrm{pH}$ of the alkaline solution is low, such as 9 , the reaction rate of kaolinite and the alkali solution is the fastest. The content of kaolinite controls the reaction rate. When the $\mathrm{pH}$ of the alkaline solution is 10 or 11 , the reaction rate of quartz and montmorillonite rapidly increases, and even exceeds the reaction rate of kaolinite, while the reaction rate of illite and chlorite with the alkali solution is slow. Therefore, the content of quartz, montmorillonite, and kaolinite controls the reaction rate when the $\mathrm{pH}$ of the alkaline solution is 10 or 11 . When the $\mathrm{pH}$ of the alkaline solution is 12 , the chlorite reaction rate is the slowest. The reaction rate is determined by the contents of four minerals: quartz, montmorillonite, illite, and kaolinite.

The experimental results show that there are great differences in the reaction rates of minerals in different concentrations of alkaline solutions. The higher the concentration of the alkali solution is, the more the kinds of minerals participate in the reaction.

3.2. Effect of Particle Size of Shale on Reaction Rate. As shown in Figure 4, the reaction between shale powder and alkali solutions shows that the alkaline erosion rate increases with the decrease of particle size. The experimental results show that the smaller the particle size, the larger the specific surface area. Therefore, the erosion effect is also stronger for the shale powder with smaller particle size. In addition, the experimental results also showed that the higher the hydroxide ion, the greater the erosion rate. It can be seen that the higher the concentration of hydroxide ions, the more severe the reaction of the shale and alkali solution.

As shown in Figure 5, the experimental results show that the smaller the size of the shale powder, the higher the concentration of silica in the alkali solution after the reaction. It can be seen that shale powder with smaller particle size can react more quickly with the alkaline solution. 


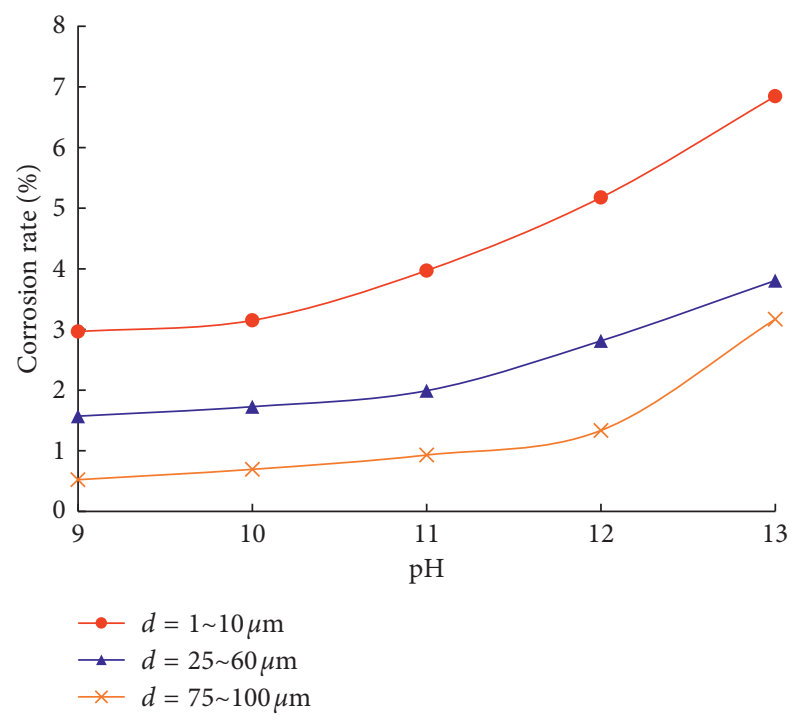

FIGURE 4: $\mathrm{pH}$ versus corrosion rate of shale powder with different sizes.

In addition, when the $\mathrm{pH}$ is 9 to 12 , the concentration of silica in the alkali solution tends to increase slowly as the $\mathrm{pH}$ increases, but when the $\mathrm{pH}$ is more than 12 , the concentration of silica in the alkali solution rapidly increases. And the data fitting results show that the silica concentration and $\mathrm{pH}$ accord with the power function. So, the experimental results also show that increased concentration of hydroxide ions can induce more intense reactions. Especially, when the $\mathrm{pH}$ exceeds 12 , the reaction rate increases faster.

According to the theory of chemical reaction kinetics, the reaction rate between the shale and alkaline solution can be expressed by the following equation [25]:

$$
J=K C^{m}
$$

In (2), $J$ is the reaction rate $(\mathrm{mol} /(\mathrm{L} \mathrm{s})) ; K$ is the reaction rate constant $\left((\mathrm{mol} / \mathrm{L})^{1-\mathrm{m}} \mathrm{s}^{-1}\right) ; C$ is the concentration of fluid ( $\mathrm{mol} / \mathrm{L})$; and $m$ is the reaction order (dimensionless).

According to the data fitting results (Figure 5), the relationship between the concentration of silicon and $\mathrm{pH}$ is in accordance with the expression of (2). In addition, the reaction between rock minerals and alkali solution can produce aluminosilicate products (Table 3 ). So, the silicon element concentration can reflect the degree of reaction between the shale and alkali solution. Based on the above analysis, the reaction kinetics equations of shale with different particle sizes and alkaline solution can be obtained (Table 4).

As shown in Table 3, for the shale with three particle sizes, the reaction constant is 0.008 to 0.048 . And the reaction order is 0.970 to 1.155 . A small reaction rate constant indicates that the reaction between shale and alkali solution occurs slowly, and a large reaction order indicates that the $\mathrm{pH}$ has a significant influence on the reaction rate $[25,26]$. So, it can be seen that both shale particle size and concentration of hydroxide ion all affect the reaction rate, and the former has a negative correlation with the reaction rate, and the latter has a positive correlation with the reaction rate.

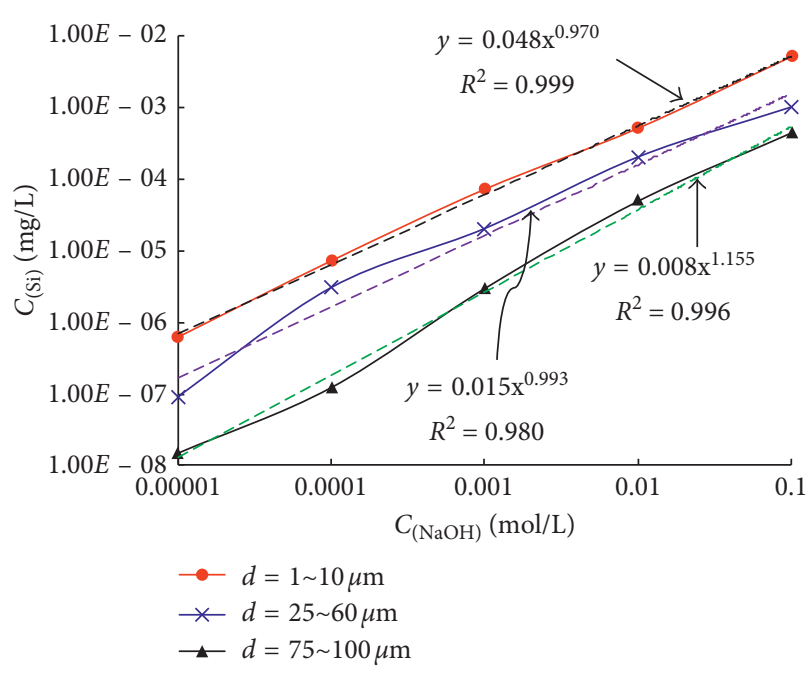

FIgURE 5: pH versus silicon element concentration in solution.

3.3. Effect of Alkaline Erosion on Shale Structure. As Figure 6 shows, soaking experiments of shale show that there were no obvious fractures seen on the shale surface before soaking into an alkaline solution. With the increasing of soaking time and $\mathrm{pH}$, the alkaline erosion caused the fracture propagation along the bedding planes of shale. When the $\mathrm{pH}$ was 11 to 12 , the alkali erosion effect for shale was reflected remarkably. The longer the soaking time was, the more obvious the fracture propagation became.

In addition, when the $\mathrm{pH}$ of the alkaline solution is 11 or 12 , it can be observed that the fracture on the shale surface was filled with brown and white sediments. In order to further confirm the above experimental phenomena, scanning electron microscopy (SEM) analysis and energy disperse spectroscopy (EDS) analysis were used to determine the erosion degree and reaction products on the shale surface. As shown in Figures 7(a) and 7(b), because of the alkali erosion effect, the shale surface appeared with a large amount of dissolution pores. Hexagon thin sheet minerals were further eroded into tiny floccules and small particles. Some products attached in the dissolution pore and presented a loose structure. As shown in Figures 7(c) and 7(e), the EDS of particles on the shale surface shows that the main component of these products are $\mathrm{CaCO}_{3}$ and $\mathrm{Fe}_{2} \mathrm{O}_{3}$, respectively, which shows that the pyrite and dolomite in the shale have reacted with the alkali solution.

The aforementioned experimental results show that the alkaline erosion effect on shale can lead to the fracture propagation along the bedding plane, which may easily result in collapse along the fractures intersecting a wellbore.

\section{Conclusion}

(1) For alkaline solutions with different $\mathrm{pH}$, the corrosion rate of minerals is not the same. The corrosion rates are as follows: kaolinite $>$ smectite $>$ quartz $>$ quartz $>$ illite $>$ chlorite when the $\mathrm{pH}$ is 9 ; smectite $>$ quartz $>$ kaolinite $>$ illite $>$ chlorite when the $\mathrm{pH}$ is 10 
TABLE 4: Reaction kinetics equation of shale with different particle sizes.

\begin{tabular}{lccc}
\hline Particle size of shale $(\mu \mathrm{m})$ & $K(\mathrm{~mol} /(\mathrm{L} \cdot \mathrm{s}))$ & $m\left((\mathrm{~mol} / \mathrm{L})^{\left.1-\mathrm{m}_{\cdot} \cdot \mathrm{s}^{-1}\right)}\right.$ & Reaction kinetic equation \\
\hline $1 \sim 10$ & 0.048 & 0.970 & $J=0.048 C_{(\mathrm{NaOH})}^{0.970}$ \\
$25 \sim 60$ & 0.015 & 0.993 & $J=0.015 C_{\mathrm{NaOH}}^{0.993}$ \\
$75 \sim 100$ & 0.008 & 1.155 & $J=0.008 C_{(\mathrm{NaOH})}^{1.155}$ \\
\hline
\end{tabular}

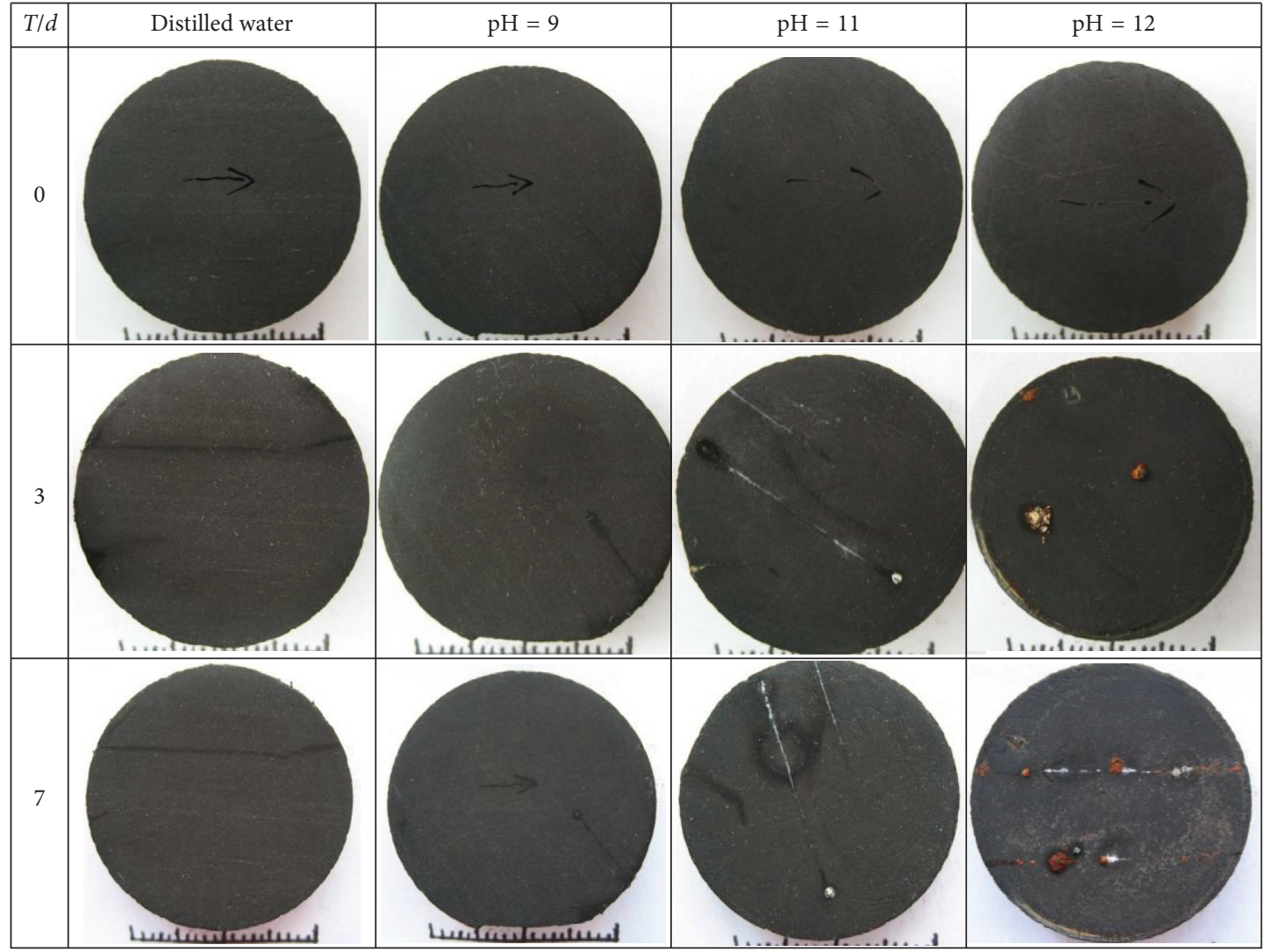

FIGURE 6: The results of shale fracture development rolling into different $\mathrm{pH}$ solutions at different times.

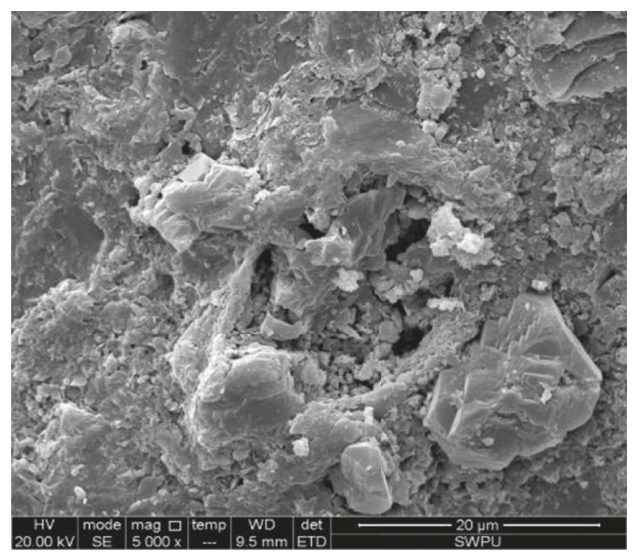

(a)

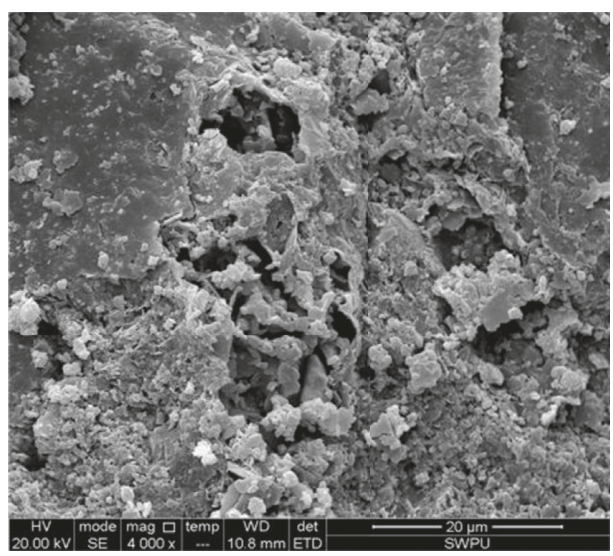

(b)

Figure 7: Continued. 


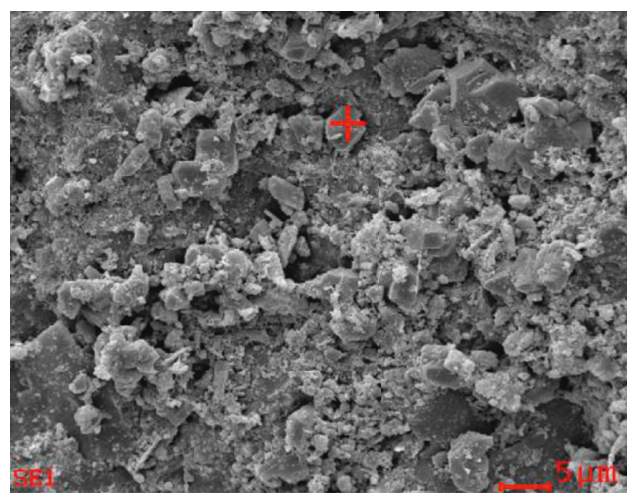

(c)

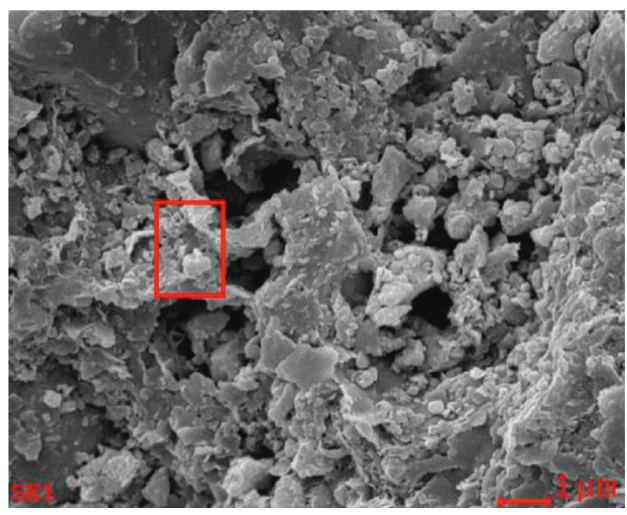

(e)

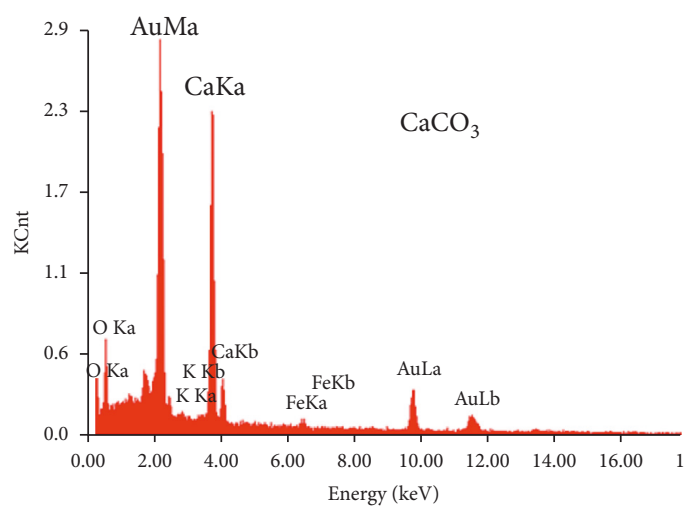

(d)

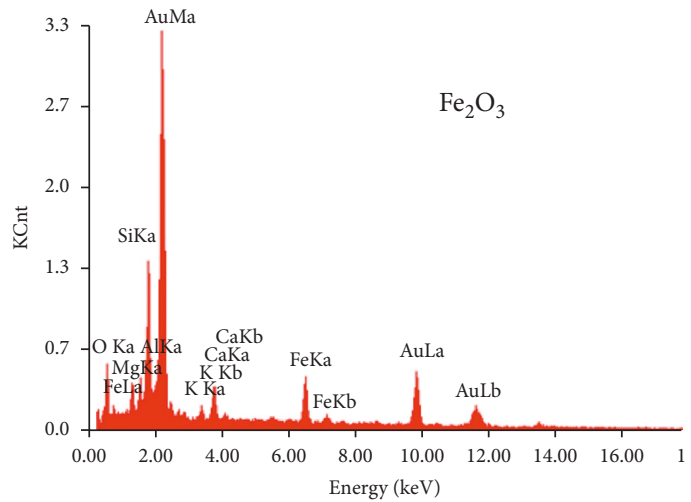

(f)

Figure 7: (a, b) SEM images show that shale was eroded by the alkaline solution. EDS maps (c-f) show that $\mathrm{CaCO}_{3}$ and $\mathrm{Fe}_{2} \mathrm{O}_{3}$ attached on the surface of shale.

or 11 ; quartz $>$ illite $>$ smectite $>$ kaolinite $>$ chlorite when the $\mathrm{pH}$ is 12 .

(2) Reaction kinetics experiments show that both shale particle size and concentration of hydroxide ion all affect the reaction rate, and the former has a negative correlation with the reaction rate, and the latter has a positive correlation with the reaction rate.

(3) The alkaline erosion effect on shale can lead to the fracture propagation along the bedding plane, which can easily result in collapse along the fractures intersecting a wellbore.

\section{Data Availability}

The data used to support the findings of this study are available from the corresponding author upon request.

\section{Conflicts of Interest}

The authors declare that they have no conflicts of interest.

\section{Acknowledgments}

The authors gratefully acknowledge the financial support from the NSFC (Natural Science Foundation of China)
(No. 51704043) and Education Department of Sichuan Province Foundations of Sichuan Province (Nos. 18ZB0074 and 18TD0015).

\section{References}

[1] H. Soroush, J. H. Sampaio, and E. Y. Nakagawa, "Investigation into strengthening methods for stabilizing wellbores in fractured formations," in Proceedings of SPE Annual Technical Conference and Exhibition, San Antonio, TX, USA, September 2006.

[2] M. E. Zeynali, "Mechanical and physico-chemical aspects of wellbore stability during drilling operations," Journal of Petroleum Science and Engineering, vol. 82-83, pp. 120-124, 2012.

[3] F. K. Mody and A. H. Hale, "Borehole-stability model to couple the mechanics and chemistry of drilling-fluid/shale interactions," Journal of Petroleum Technology, vol. 45, no. 11, pp. 1093-1101, 1993.

[4] J. Zhang, T. M. Al-Bazali, M. E. Chenevert, and M. M. Sharma, "Factors controlling the membrane efficiency of shales when interacting with water-based and oil-based muds," SPE Drilling \& Completion, vol. 23, no. 2, pp. 150-158, 2008.

[5] S. W. Wong and W. K. Heidug, "Borehole stability in shales: a constitutive model for the mechanical and chemical effects of drilling fluid invasion," in Proceedings of SPE/ISRM Conference, Delft, Netherlands, August 1994. 
[6] F. J. Santarelli and S. Carminati, "Do shales swell? A critical review of available evidence," in Proceedings of SPE/IADC Drilling Conference, Amsterdam, Netherlands, FebruaryMarch 1995.

[7] H. Abass, A. Shebatalhamd, M. Khan et al., "Wellbore instability of shale formation: Zuluf Field Saudi Arabia," in Proceedings of SPE Technical Symposium of Saudi Arabia Section, Dhahran, Saudi Arabia, May 2006.

[8] Y. F. Yu, Y. L. Kang, L. J. You, Q. Chen, and B. Yang, "Alkali corrosion: a new mechanism of shale borehole instability," Acta Petrolei Sinica, vol. 34, pp. 983-988, 2013.

[9] Y. L. Kang, G. Q. Zhou, L. J. You, and X. C. Li, "Mitigating borehole instability and formation damage with temporary shielding drilling fluids in low permeability fractured reservoirs," in Proceedings of SPE European Formation Damage Conference \& Exhibition, Noordwijk, Netherlands, June 2013.

[10] B. Wu and C. P. Tan, "Effect of shale bedding plane failure on wellbore stability-example from analyzing stuck-pipe wells," in Proceedings of 44th U.S. Rock Mechanics Symposium and 5th U.S.-Canada Rock Mechanics Symposium, Salt Lake City, UT, USA, June 2010.

[11] E. Van Oort, J. E. Friedheim, T. Pierce, and J. Lee, “Avoiding losses in depleted and weak zones by constantly strengthening wellbores," in Proceedings of SPE Annual Technical Conference and Exhibition, New Orleans, LA, USA, October 2009.

[12] V. X. Nguyen and Y. N. Abousleiman, "Real-time wellboredrilling instability in naturally fractured rock formations with field applications," in Proceedings of IADC/SPE Asia Pacific Drilling Technology Conference and Exhibition, Ho Chi Minh City, Vietnam, November 2010.

[13] B. Aadnøy and R. Looyeh, Petroleum Rock Mechanics, Gulf Professional Publishing, Boston, MA, USA, 2011.

[14] R. Kumar, S. V. Perumalla, and S. K. Verma, "Geomechanical evaluation of mud losses and wellbore instability in Mumbai high north field-implications to infill drilling and reservoir development," in Proceedings of SPE Oil and Gas India Conference and Exhibition, Mumbai, India, March 2012.

[15] S. Li, Y. L. Kang, L. J. You, D. Q. Li, and Lian ZH, "Experimental and numerical investigation of multiscale fracture deformation in fractured-vuggy carbonate reservoirs," Arabian Journal for Science and Engineering, vol. 39, no. 5, pp. 4241-4249, 2014.

[16] Y. F. Li, Y. Q. Fu, G. Tang, C. Y. She, J. H. Guo, and J. Y. Zhang, "Effect of weak bedding planes on wellbore stability for shale gas wells," in Proceedings of IADC/SPE Asia Pacific Drilling Technology Conference and Exhibition, Tianjin, China, July 2012.

[17] S. C. Xiong, "Study on alkaline transmission mechanism in porous media," Doctoral dissertation, pp. 10-70, Chinese Academy of Sciences, Beijing, China, 2009.

[18] X. N. Xie and C. Q. Liu, "A kinetic experiment on alkaline consumption and its analysis," Oilfield Chemistry, vol. 6, pp. 243-246, 1989.

[19] H. T. Wang, "The dissolution and corrosion characteristics research of alkali ternary system to the reservoir minerals," Master thesis, pp. 1-67, Jilin University, Changchun, China, 2012.

[20] S. M. Mohnot, J. H. Bae, and W. L. Foley, "A study of mineral/ alkali reactions," SPE Reservoir Engineering, vol. 2, no. 4, pp. 653-663, 1987.

[21] L. Huang, P. H. Yang, and T. L. Qin, "A study of caustic consumption by clays," Petroleum exploration and development, vol. 4, pp. 64-75, 1987.
[22] J. M. Soler, "Reactive transport modeling of the interaction between a high-pH plume and a fractured marl: the case of Wellenberg," Applied Geochemistry, vol. 18, no. 10, pp. 1555-1571, 2003.

[23] M. Deng and M. S. Tang, "Mechanism and prevention of alkali-dolomite reaction," Journal of Nanjing University of Chemical Technology, vol. 20, pp. 1-7, 1998.

[24] W. Sun, Y. H. Hu, G. Z. Qiu, and W. Q. Tan, "A study on electrochemical corrosion of surface reaction of pyrite in high alkali environment," Mining Metallurgical Engineering, vol. 22, pp. 51-54, 2002.

[25] M. Fertani-Gmati, K. Brahim, I. Khattech, and M. Jemal, "Thermochemistry and kinetics of silica dissolution in $\mathrm{NaOH}$ solutions: effect of the alkali concentration," Thermochimica Acta, vol. 594, pp. 58-67, 2014.

[26] Q. Li, "The study for kinetics behavior of high viscosity acidrock reaction," Doctoral dissertation, pp. 1-84, Chengdu University of Technology, Chengdu, China, 2013. 

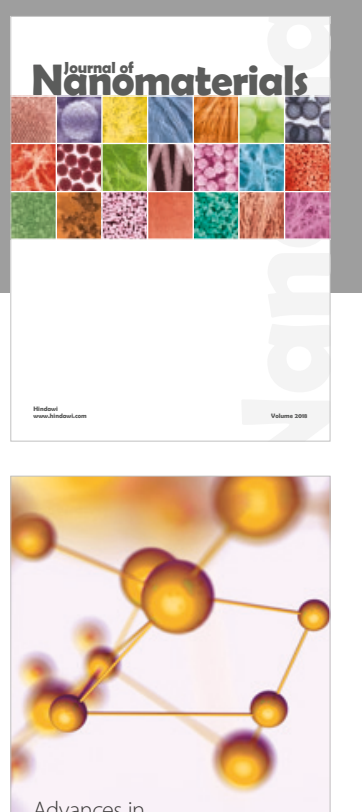

Physical Chemistry
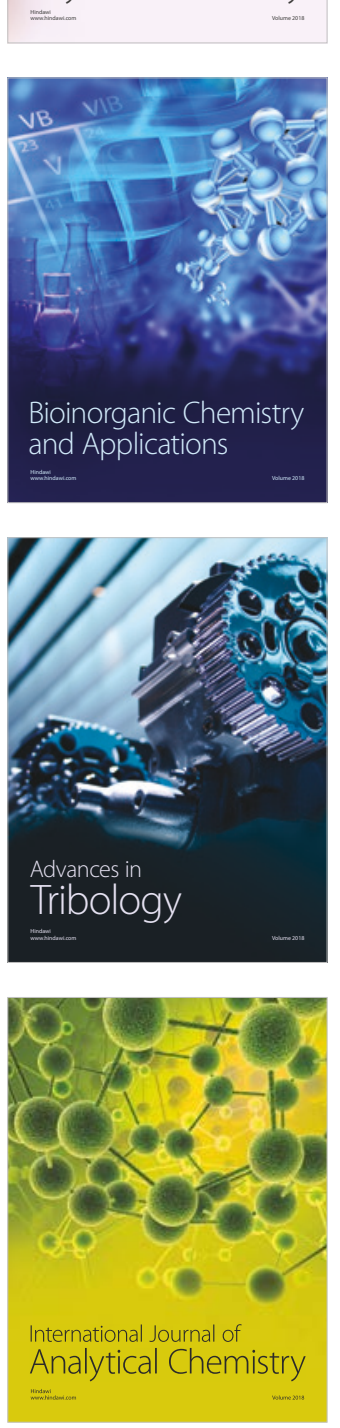

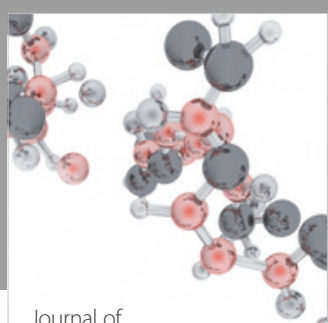

Analytical Methods

in Chemistry

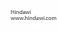

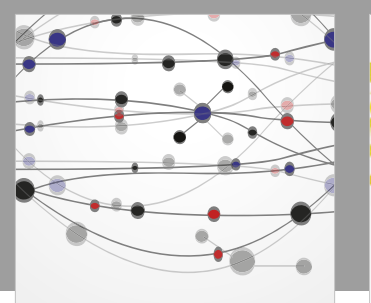

The Scientific World Journal

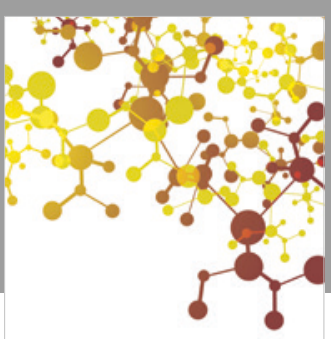

Journal of

Applied Chemistry
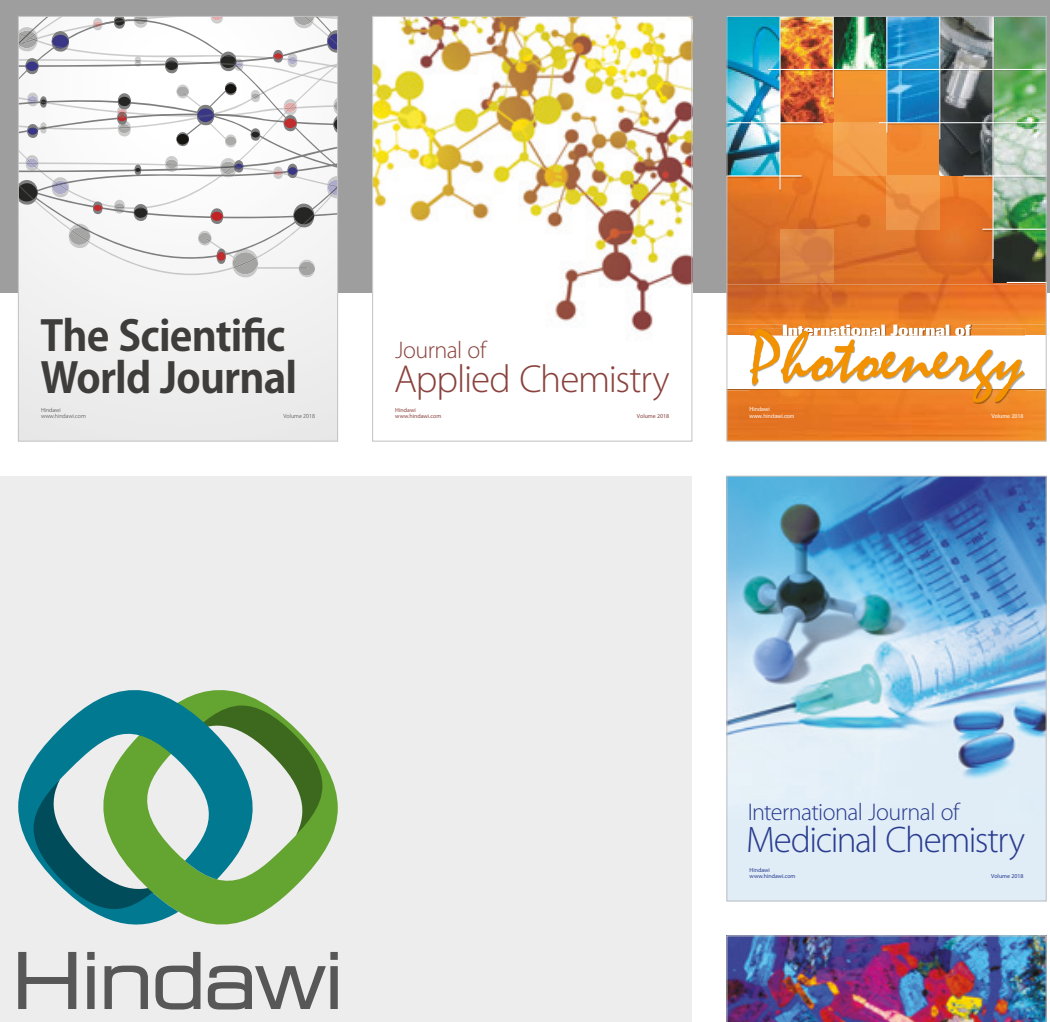

Submit your manuscripts at

www.hindawi.com
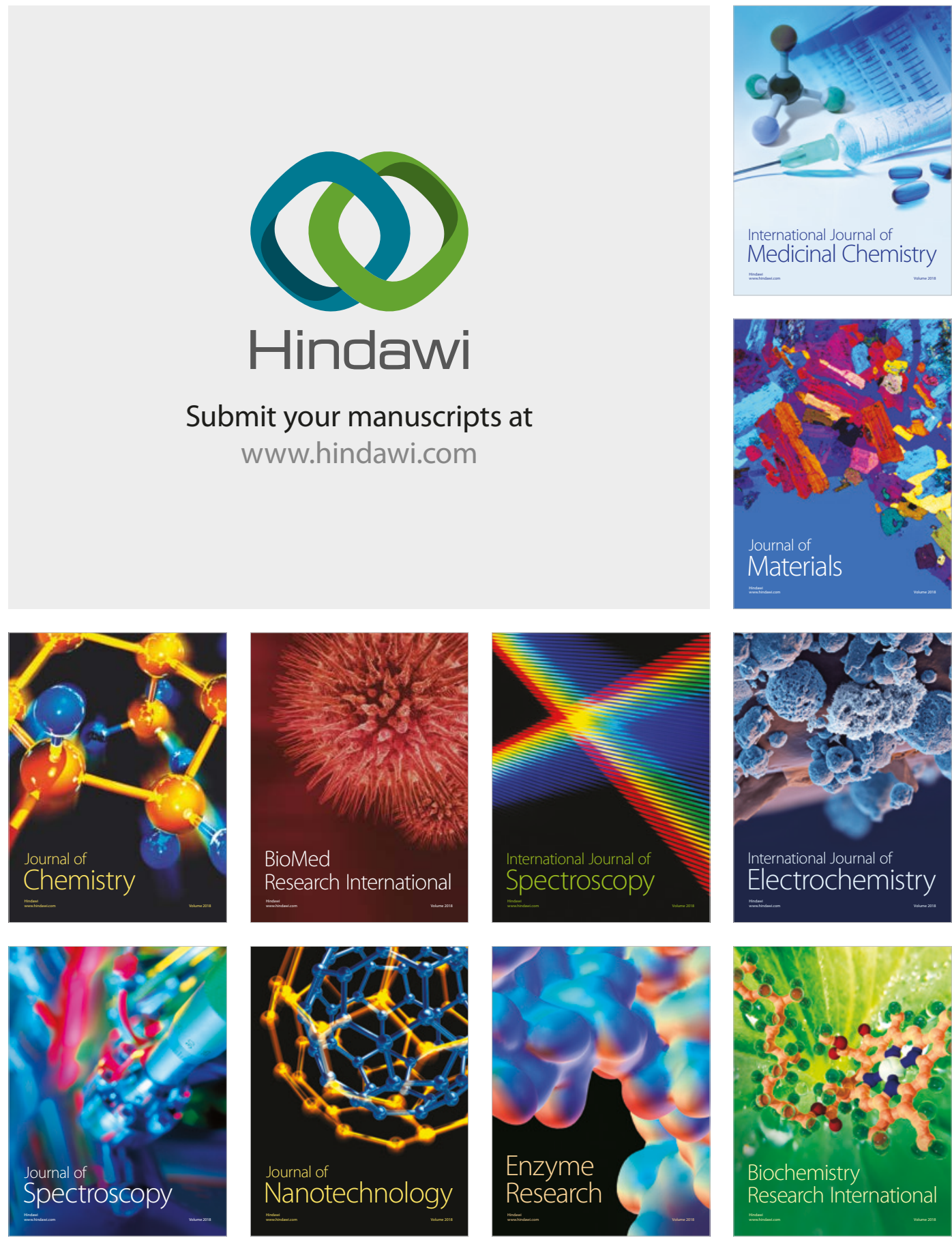
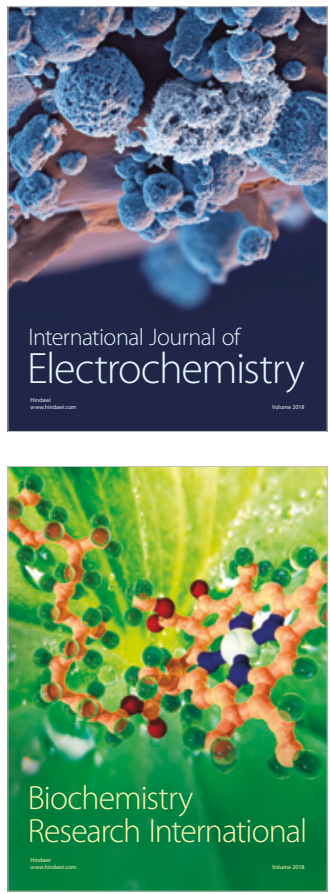